International Journal of Agriculture, Environment and Bioresearch

Vol. 4, No. 05; 2019

ISSN: $2456-8643$

\title{
TYPOLOGY OF CONFLICT AND WATER USE IN LAGOON IN THE SEN RIVER DELTA IN BENIN (WEST AFRICA)
}

\author{
ASSABA H. Martin $^{2}$; SOVI Emmanuel ${ }^{1}$; AZIAN Donatien ${ }^{1}$ and VISSIN Expedit W. ${ }^{1}$ \\ ${ }^{1}$ laboratoire Pierre Pagney, Climate, Water, Ecosystems And Development (Laceede), University Of Abomey-calavi \\ (Benin) \\ ${ }^{2}$ Laboratory Of Biogeography And Environmental Expertise (Labee), University Of Abomey-calavi
}

http://doi.org/10.35410/IJAEB.2019.4434

\begin{abstract}
The present study focuses on the issue of uses and conflicts related to the use of water in the Sô delta in Benin, a lake territory, where the issue of water resources management has always posed problems. To achieve this objective, the methodological approach used focuses on three stages: documentary research; - the collection and processing of data; - the analysis of the results.

The data used for this work are both qualitative and quantitative. They are extracted from field surveys which consisted of interviews with the persons in charge of the management of the structures, the local authorities and the beneficiary populations of the drinking water works. This methodology has led to some results.
\end{abstract}

The results obtained show that the delta of the Sô River has a good drainage network rich in plans and permanent watercourses. But four types of conflicts have been identified. The first type of conflict and the most frequent (35\%) in the delta of the Sô River concerns the management of structures. It opposes the members of the management committees or the farmers and the populations (customers). The second category of conflict identified is related to land tenure on the water. Conflicts over land-water are often created by inheritance sharing (72\% of the way in which land is acquired) or the sale of property (12\%). The third type of conflict arises among fishermen or between fishermen and lagoon sand operators. These conflicts are often due to interactions or the influence of one activity on the other. In more than $80 \%$ of the cases encountered, fishermen complain about the consequences of sand dredging on their activities. As for the conflicts between fishermen, they are related to more than $90 \%$ of the cases encountered, to land issues (limits of a territory). Finally, other types of conflict arise during the gathering of women, especially around points / sources of water, or when collecting debts.

The majority of Tofinnu carry out their economic activities on water bodies (Nokoué Lake, Sô River or Ouémé River). For the good running of their economic activities on the one hand, and for socio-cultural reasons on the other hand, $82.1 \%$ of the local population resort to cultural and cultural practices. These are rituals, purifications, sacrifices and traditions.

It is therefore important to clarify the role and responsibilities of each stakeholder involved in the management of the water resources of the Municipality of Sô-Ava to finish, a little time with the many problems that hinders the achievement of the objectives of IWRM. 
(Benin)

Keywords: Management, typology, water resource, lacustrine, Sô-ava, conflict

\section{INTRODUCTION}

Although our planet is $70 \%$ water and is a renewable resource (thanks to the water cycle), freshwater quality is a scarce resource (Calvo-Mendieta, 2016). Indeed, water issues for the twenty-first century are multiple: the high demands of megacities, global warming, lack of water, waterborne diseases, floods, drought, etc. If water is to respond to these challenges, men must meet the challenge of learning how to share this resource, providing safe water for all, managing gaps and surpluses (Anctil 2008).

These are the challenges that create conflicts of use around water. There are many conflicts, and many are the uses of water. Water is the breeding ground for flora and fauna, it contributes to the drinking water supply of populations, it is used to wash, clean or cool in the production process, as well as for irrigating crops (Schneier-Madanes , 2010). It is also the support of activities like navigation, fishing, the walk (Lasserre and Descroix, 2011)

The municipality of Sô-Ava located entirely in the deltaic complex Ouémé-Sôest facing these different conflicts and uses related to water. It has a very important hydrographic network which covers almost half of its territory. Thanks to the exploitation of the fishery resources, its hydrographic network is also favorable for the traffic of the petroleum products and various types of human activity source of pollution: residues of heavy metals (lead and mercury), rejection of the waste (garbage, biomedical waste), human and animal excreta etc.) by the people. The objective of this work is to establish the typology of uses of water resources in the commune of Sô-ava in the delta of the Sô River.

\section{Presentation of the study environment}

The study area corresponds in part to the lower Ouémé valley in the lower basin of the Sô River at Sô-Ava. It therefore includes the Commune of Sô-Ava and the northern part of Lake Nokoué (Figure 5). The study area is a wetland generally between $6^{\circ} 24^{\prime} 30^{\prime \prime}$ and $6^{\circ} 38$ 'north latitude and between $2^{\circ} 20^{\prime}$ and $2^{\circ} 35^{\prime} 10^{\prime \prime}$ east longitude. 


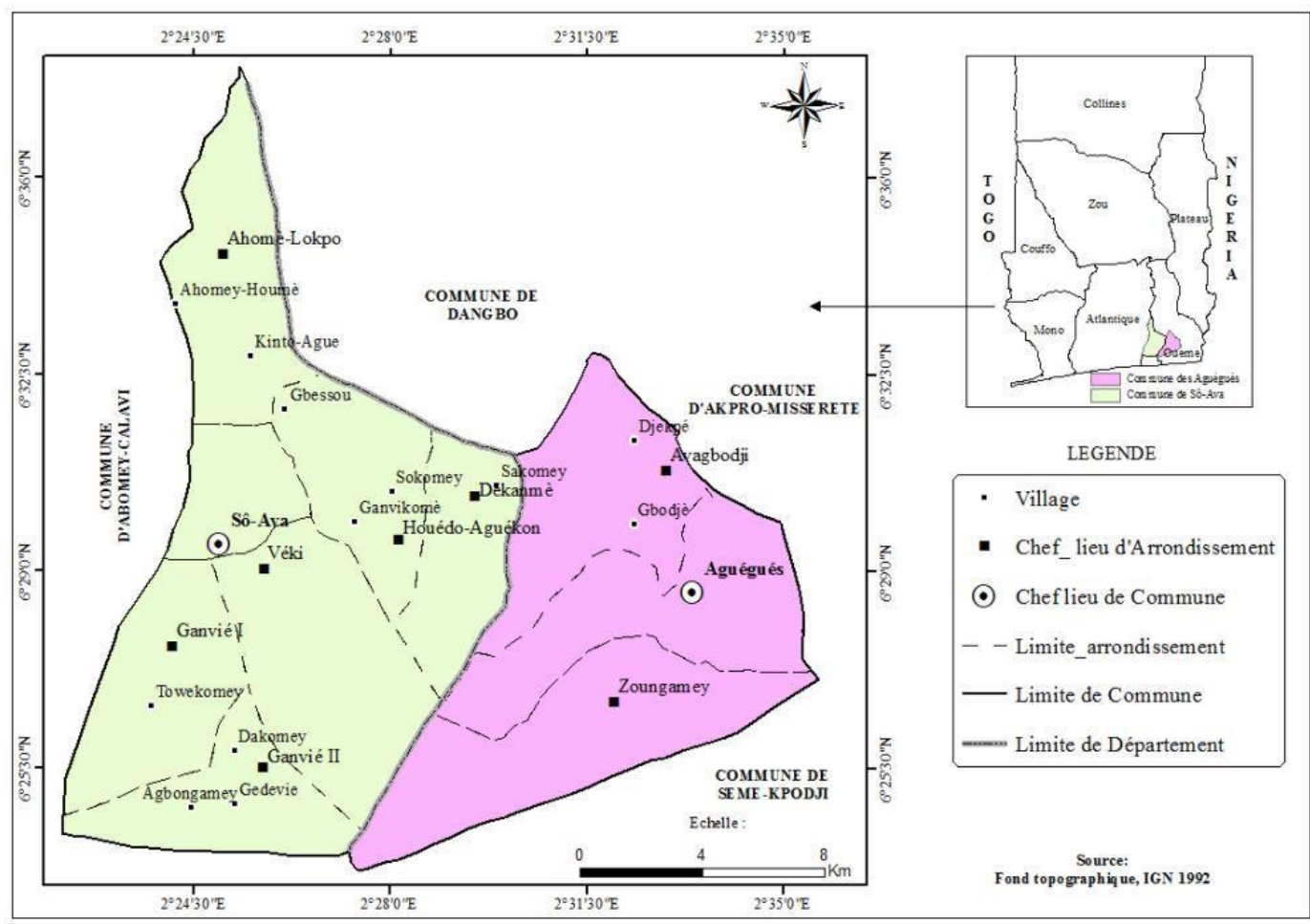

Figure 1: Situation of the study environment

The lower valley of Ouémé comprises on the one hand the middle delta and on the other hand the low delta. The delta of Ouémé has the shape of an elongated triangle and measures $90 \mathrm{~km}$ from north to south. The lagoon of Porto-Novo constitutes its southern facade. To the west, the vast deltaic plain is bounded by the marshes of the Sô river and to the east by the Pobè-Porto-Novo plateau. Its surface area varies from about $1000 \mathrm{~km}^{2}$ according to Welcomme (1971) to $9000 \mathrm{~km}^{2}$ (Lang and Paradis, 1977).

The landscape is shaped by the alternation of high and low waters, floods and floods occupying the lower valley of the Ouémé River $(510 \mathrm{~km})$ and the delta of the Sô River $(84.4 \mathrm{~km})$. Sediments carried by wintering floods from the north of the country enrich the environment and promote its biological productivity (Colombani et al., 1972).

Given its geomorphological configuration, the study environment has a high water availability. The hydrographic network is located in the lower basin of the Sô-Ouémé complex in Sô-Ava and in the Aguégués. Figure 7 illustrates the distribution of surface water in the study environment. 


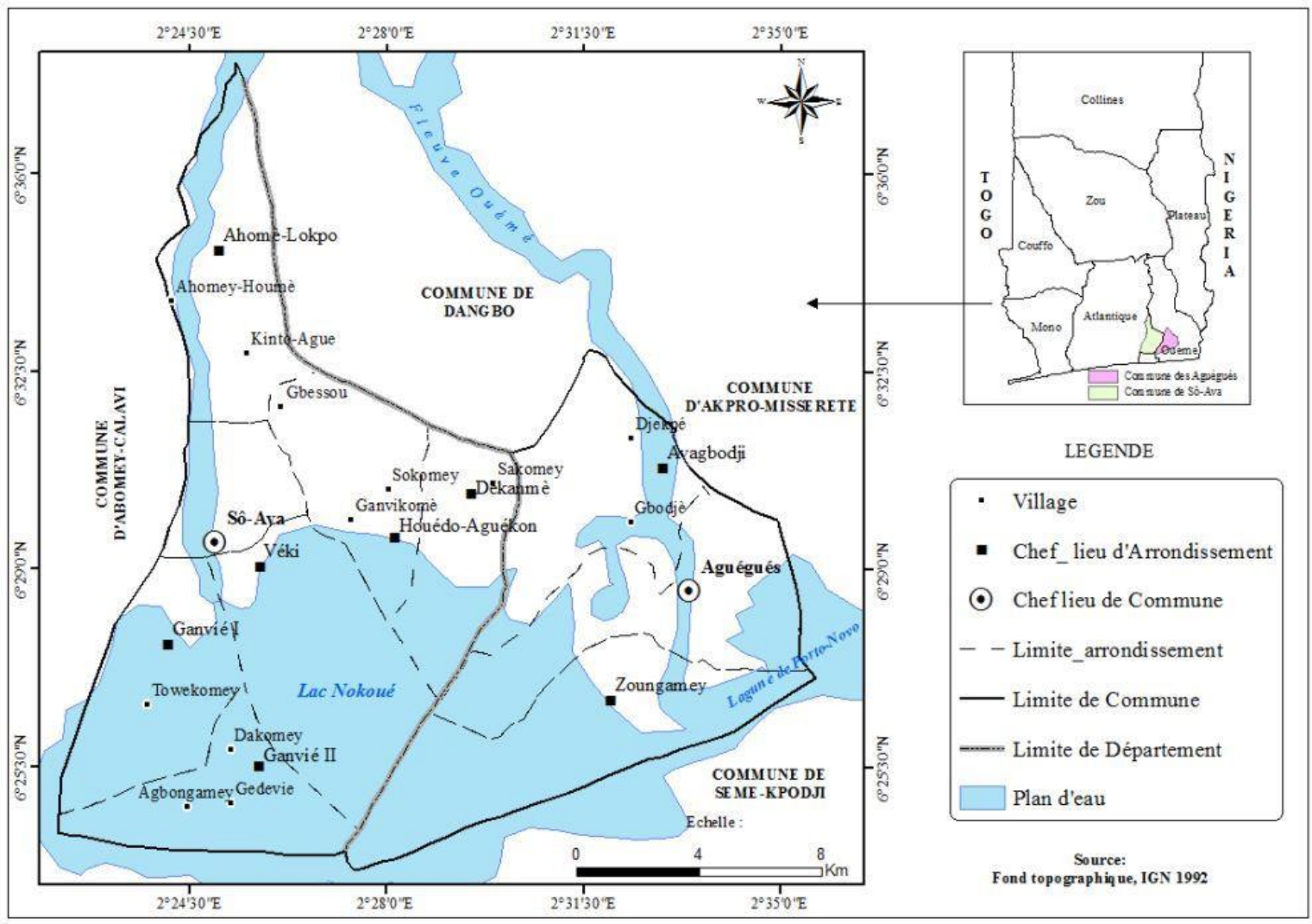

A brief history of sedimentary terrains in southern Benin provides a better understanding of the geological and morphological structure of the lower Ouémé basin (Colombani et al., 1972).

\section{METHODOLOGICAL APPROACH}

The methodological approach focuses on data collection, data processing and results analysis to determine the types of conflicts and the different uses of water by populations in the Sô delta.

\subsection{Determination of sampling}

Surveys were therefore conducted in all Arrondissements de la Commune to collect the greatest diversity of information on water use in the Sô delta. Thus, the surveys were conducted randomly, with 150 households spread over all of the District's 07 Arrondissements (the villages selected by Arrondissement have the chance to be drawn only once). Of the 42 villages in the commune, 10 villages were surveyed. The sample size was determined by the probabilistic method of Schwartz (1995). 150 households were interviewed in the 10 villages

\subsection{Data, technique, data collection equipment and data processing used}

The data used for the determination of the different conflicts and uses of water come from the documentary information and field data relating to the transport activities, the inland fisheries 
collected near the heads of households, fishermen, politicians religious and resource persons with at least 10 years of seniority.

The investigations carried out were coupled with direct observations in the field. Materials such as GPS (Global Positioning System) for taking geographic coordinates for the realization of the map of the study area and also a digital camera for taking snapshots.

\subsection{Data processing and results analysis}

Qualitative data was coded and entered using the Excel spreadsheet. The analysis of the survey data was done using SPSS software (Statistical Package for the Social Sciences version 16.0) for the descriptive statistics (numbers, percentage of modalities).

\section{RESULTS AND DISCUSSION}

\subsection{Typology of water use conflicts in the Sô delta}

Water sources or points are areas of encounter between people of different origins. In the Sô delta, the uneven distribution of drinking water supplies means that some households travel an average of two kilometers to fetch drinking water. It is inevitable that conflicts arise around these sources. Figure 3 presents the main conflicts identified during field investigations.

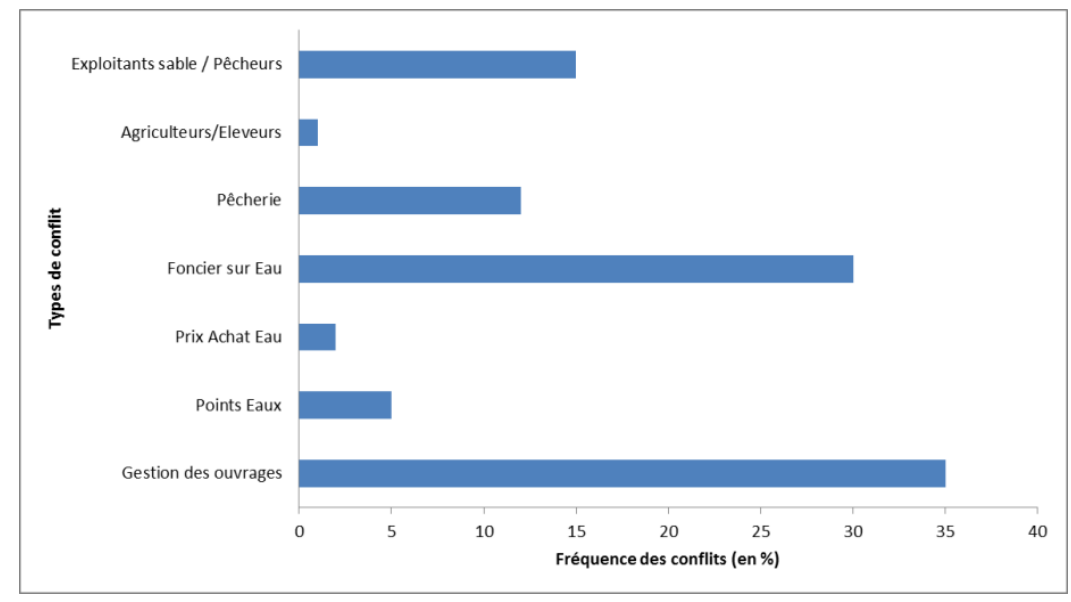

It can be seen from figure 3 that the most frequent conflicts in the delta of the River Sô relate to the management of the structures. Indeed, these kinds of conflicts are between the members of the management committees or the farmers and the populations (customers). They generally relate to the payment of royalties or the payment of a debt relating to a sale / purchase of water operation.

The second category of conflict identified is land tenure on the water. Like the conflicts that occur most often in the Land Communes, Lake Commons such as the Municipality of Sô-Ava knows a high rate of conflicts related to land. In this case, it is the land on the water. Indeed, all 
surfaces of the water bodies are shared and each portion is the property of the town hall or an individual. Conflicts over land-water are often created by inheritance sharing ( $72 \%$ of the way in which land is acquired) or the sale of property (12\%).

The third type of conflict arises among fishermen or between fishermen and lagoon sand operators. These conflicts are caused by interactions or the influence of one activity on the other. In more than $80 \%$ of the cases encountered, fishermen complain about the effects of sand dredging on their activities. As for the conflicts between fishermen, they are related to more than $90 \%$ of the cases encountered, to land issues (limits of a territory).

Finally, other types of conflict arise during women's slaughters, especially around water points / sources, or when debt is recovered. Conflicts between herders and farmers are almost absent in the delta of the Sô River.

The settlement of conflicts is done either at the village chief or at the level of security authorities (police station). The most mundane cases are settled miserably while land disputes over water are most often brought to the courts.

\subsection{Conventional uses of water in the Sô delta}

Investigations in the Sô delta have identified several forms of water use by Tofinnu populations. The proportions of the most frequent forms are shown in Figures 4 and 5. Figure 4 shows the uses for which the water of the distribution works is intended, while Figure 5 shows the forms of use of surface water (water from the Sô river).

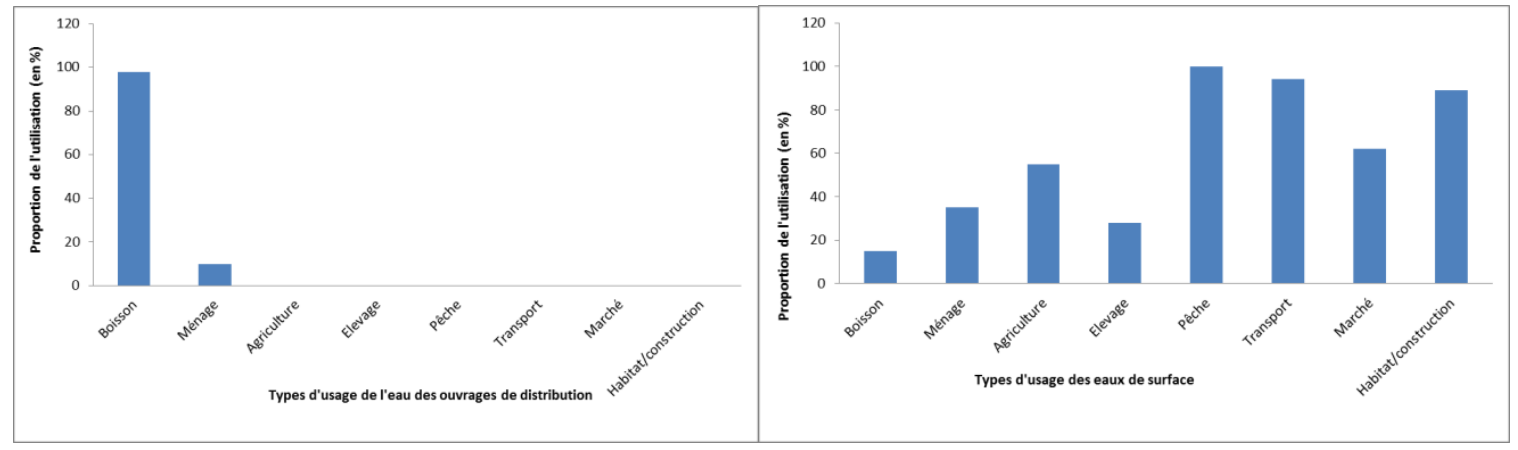

Figure 4: Forms of Water Use in Distribution Works

Figure 5: Forms of Surface Water Use

The examination of figure 4 shows that the water from the works is exclusively used in the household, either as drinking water or for other household needs (cooking, laundry, shower, etc.).

Plate 1 presents some photographs that illustrate certain practices related to the use of surface water in the delta of the Sô River. 


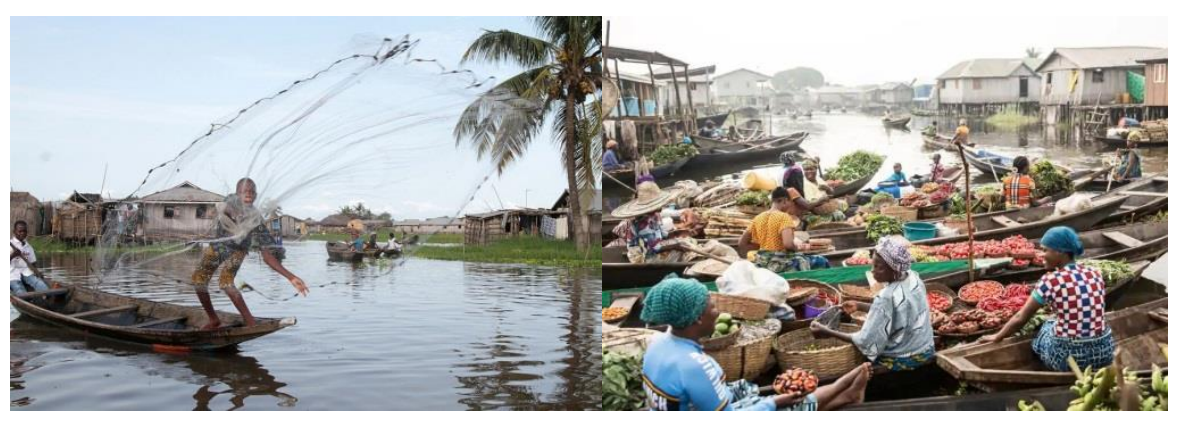

Photo 1: Fishing activity on the water of the river Photo 2: Floating market on the river Sô

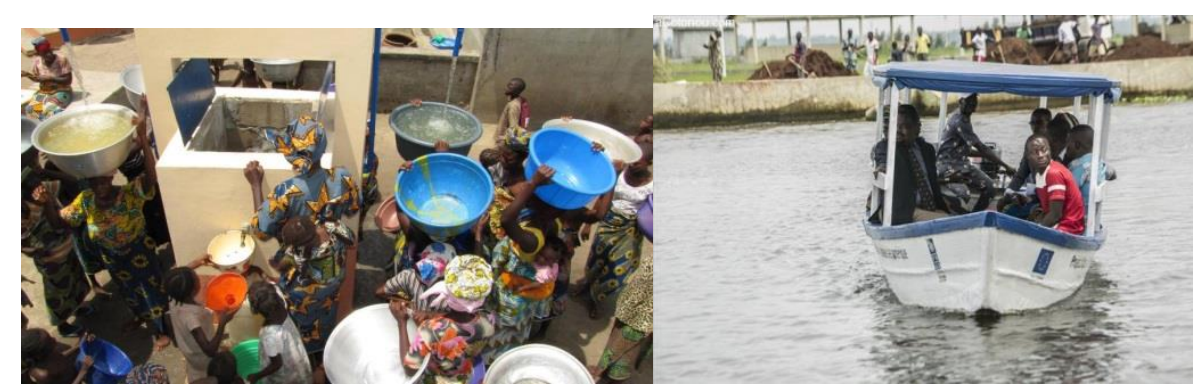

Photo 3: Gathering around a Borne Fountain in Vekky Photo 4: Mode of Transport on the river in Sô-Ava

Plate 1: Some forms of water use in the Sô River delta , Shooting: Sovi, 2019

The analysis of Figure 5 and the photographs in Plate 1 show that the river's waters are used by the people for the following purposes in order of importance:

- Fishing activities in the Sô River and the water bodies of the basin;

- River transport. The displacements between localities take place more than $90 \%$ of the cases on the surface of the water by means of a canoe or a motorized boat. This form of water use plays an important role in opening up the environment. In fact, the external river navigation makes it possible to transfer the big agglomerations of Grand Nokoué (Abomey-Calavi, Cotonou, PortoNovo), Wemenu localities or even Nigeria.

- Housing construction (use of water for masonry work) and engineering structures;

- The holding of certain periodic markets on the water in canoes;

- The use of surface water to irrigate agricultural crops;

- Use of river water for some household needs (cooking, laundry, shower, etc.);

- Use of river water for watering domestic livestock;

- Use of river water as drinking water by the most needy households. 


\subsection{Cultural and cultural uses of water in the Sô delta}

The majority of Tofinnu carry out their economic activities on water bodies (Nokoué Lake, Sô River or Ouémé River). For the good running of their economic activities on the one hand, and for socio-cultural reasons on the other hand, $82.1 \%$ of the local population resort to cultural and cultural practices. These are rituals, purifications, sacrifices and traditions.

\section{Rituals}

A newborn baby who crosses the river for the first time, is subjected to the ritual of:

- Put a coin on the child's head;

- Discard the used piece in the river.

This means that the child has been paid for crossing the water and thus acquires all the rights to use the water during his life.

\section{Purifications}

There is a sacred part of the river Sô in Kinto called Zounvô where it is forbidden to throw a net (the fishing practice hawk). According to the story told by a notable Kinto-Zunclan, years ago, a fisherman had defied this ban by throwing his net to this forbidden place. He thought he was catching large and numerous fish that were pulling the net. The latter having raised his net, found a black pot surrounded by twigs and containing hot tea. Once arrived home this fisherman has given up. Zunvo being sacred, the water of this river serves to purify the man from evil spells.

\section{Sacrifices}

At the time of the recession, the followers of the traditional cults consult the Fâ which informs them about the sacrifices to make in the river so that the fishing of the year is profitable and economic. The Fâ also indicates the fisherman who must first perform the fishing activities in the river, just after the sacrifice so that the fishing of the year is blessed and fruitful. Sacrifices in the Sô River are therefore important for the economic prosperity of households.

\section{Tradition}

In lake villages, it is a tradition to extinguish fire as a group in case of fire. Thus, any individual who has played the role of firefighter or helped extinguish the fire of a fire, must put his feet in the water of the river so that his house (or his residence) is burned in turn. Failure to respect this tradition poses a high risk of seeing one's own concession burned sooner or later.

\subsection{Cost of water and sales service}

3.4.1. Service for the sale of water from complex structures: village water supply (AEV) and autonomous water stations (PEA) 
The complex water supply structures that are the Village Water Additives (AEV) and the Autonomous Water Stations (PEA) are collectively managed in the Municipality of Sô-Ava by the beneficiary populations organized in the Association des Usagers d'Eau. Water (AUE). This association brings together all the inhabitants who use water, living in a village of

Each borough served by an AEV or a PEA. The missions of this association include:

- Promote and prepare the implementation of village water supply;

- Ensure the public service of distribution of drinking water;

- Represent the users for the whole relating to the service of drinking water;

- Delegate day-to-day management of the system to an operator and enter into a maintenance contract;

- Manage the equipment, the durability and the renewal of the equipment.

To ensure the effective management of the structure, a committee responsible for the management of standpipes is set up. Also, it ensures the recruitment and the follow-up of a fountain, for the sale of the water at the level of each standpipe. The fontainier is remunerated in proportion to the quantity of water sold.

In the Commune of Sô-Ava, the cubic meter (m3) of water has risen from 600 francs to $405 \mathrm{~F}$ CFA to the fountains. The water is sold in retail to households at 15 F CFA the basin of 25 liters capacity. The fees to be paid to the town hall, the ACEP and those relating to renewal are respectively equal to 20 francs / m3, 10 francs / m3 and 100 francs / m3.

Despite the relatively low cost of water in the Sô delta, about $60 \%$ of the population of Sô-Ava commune prefers to use river water for their domestic purposes. During the flood especially, the turnover of the managers of the works drops considerably. Thus, according to an operator of the Ahomey-Ounmè Autonomous Water Station (PEA), a 15-m3 castle intended to serve a population of more than 2,000 inhabitants lasts about three weeks before emptying.

The recourse to the waters of the river by the populations is considerable. The reasons given by them relate respectively to the uneven distribution of water supply works. Also, the populations estimate that the selling price of the water is relatively high in their locality, compared to their periodic income. The third reason that seems to be the main one is the availability of water from the river, a free source that offers a natural and inevitable choice to the people.

The use of what is a "free water" pushes some households who feel unhappy to wait for the operations of emptying the works before obtaining water, despite the poor quality of it. Photo 8 shows residents of Dékanmeyrecuperating free soiled wastewater for domestic purposes. 


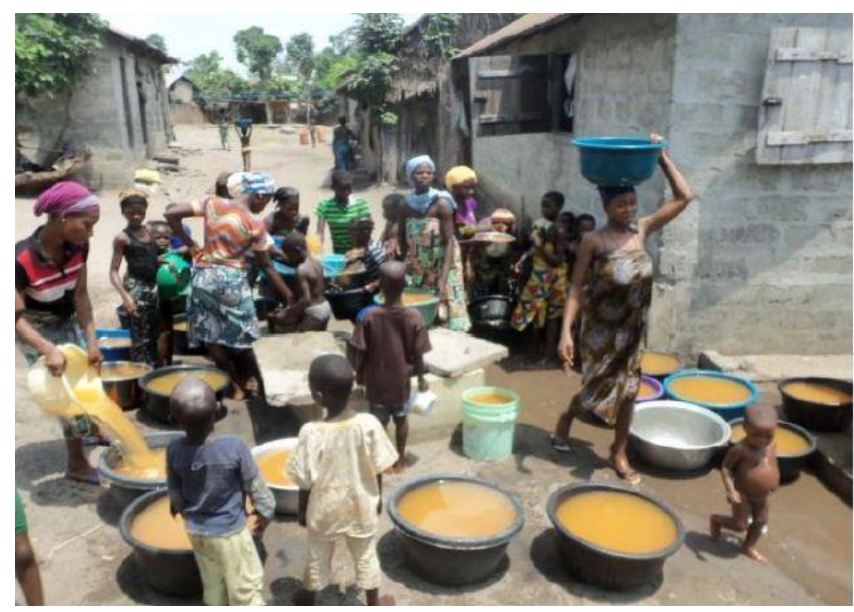

Photo 8: Recovery of dirty wastewater by residents of Dékanmey

Shooting: Sovi, 2018

\subsection{Sales Department of the National Water Company of Benin (SONEB)}

The distribution networks of the National Water Company of Benin (SONEB) are only installed in Sô-Ava, chief town of the Commune. About $10 \%$ of the population of this urban district is literate and this segment of the population is a potential clientele for SONEB. The water of the SONEB is managed by the agents of the said agency who are in charge of the maintenance of the equipment and the distribution of the monthly invoices to the subscribers. The cubic meter $(\mathrm{m} 3)$ of SONEB water is fixed at 198 CFA francs for the first $5 \mathrm{~m} 3$ and 415 CFA francs for the second tranche after the $5 \mathrm{~m} 3$.

In view of these results, strategic directions have been formulated:

- Strengthen the intervention capabilities of the technical division of the town hall;

- To reinforce the capacity of comprehension of the actors of the management of the works on the reforms in progress;

- Take steps to improve the financial indicators for managing VTEs;

- Opt for the medium-term professionalisation of the management of VTEs.

\section{CONCLUSION}

At the end of this research, it appears that the municipality of Sô-ava in the delta of the Sôa River has a high potential for water resources. But awareness of the larvality of water is relatively recent and water has for a long time been regarded as an inexhaustible resource by the 
populations. In this sense, the functions fulfilled by water are also numerous: consumption, production, support activities, purification, management. These multiple features often lead to conflicts between the various water users (and / or managers) in the study environment.

The conflicts of use on water can take very different forms, but it is necessary to distinguish the latent conflicts (or tensions) of the proven conflicts. The first ones correspond to a potential competition between certain uses, without particular mobilization of actors, whereas the conflicts have come to intervene actors (users in the broad sense), who are mobilized (legal actions, demonstrations, appropriation of space, even violence ...) to hear their interests.

It should be noted that, like the conflicts that occur most often in the Land Communes, the Lake Commons such as the Municipality of Sô-Ava knows a high rate of conflicts related to land. In this case, it is the land on the water. Indeed, all surfaces of the water bodies are shared and each portion is the property of the town hall or an individual.

This situation can lead to consequences that can harm the different layers of this same population. The surveyed households perceive these conflicts differently from one district to another. These conflicts, which hamper community management of simple structures, therefore call for the professionalization of the management of resources.

\section{REFERENCES}

-Anctil F. (2008): Water and its challenges. Quebec, Presses of Laval University. 228 p.

-Calvo-Mendieta I., (2016): Conflicts of use around water, DOI: 10.4000 / books.editionscnrs.9970 pp.184-185.

-Colombani J., J. Sircoulon, F. Moniod \& J. Rodler (1972): Monograph of the delta of Oueme. Rapp. O.R.S.T.O.M, Bydrol. France, Bondy 1, 200 p.

-Lang, J. and G. Paradis, (1977): An example of sedimentary environment, biodetitic, non carbonate carbonate continental, Holocene in intertropical climate: the marginal-littoral domain of southern Benin. (In Dahomey). Rev.Géogr. Phys. Geol. dyn. (Paria) 19, pp.295-312.

-Lasserre F. and Descroixl. (2011): Waters and territories. Voltage, Cooperation and Geopolitics of Water, Presses de l'Université du Québec, 285 p.

-Schneier-Madanes G. (dir.) (2010): Globalized water. The governance in question, Paris, Découverte, coll. Research, 492 p.

-Welcomme R. L., (1971): A description of certain indigenous fishing methods fromshern Dahomey. J, Afr. too much. Hydrobiol. Fish. 1, pp. 128-140. 